\title{
Isolation and functional characterization of novel biosurfactant produced by Enterococcus faecium
}

\author{
Deepansh Sharma ${ }^{1,2}$, Baljeet Singh Saharan ${ }^{1 *}$, Nikhil Chauhann ${ }^{3}$, Suresh Procha ${ }^{4}$ and Sohan Lal ${ }^{4}$
}

\begin{abstract}
The objective of the present study was to isolate the biosurfactant (BS) producing lactic acid bacteria (LAB) from traditional fermented food (buttermilk) and its functional and structural characterization. BS isolated from strain MRTL9 reduced surface tension from 72.0 to $40.2 \mathrm{mN} \mathrm{m}^{-1}$. The critical micelle concentration (CMC) of BS was $2.25 \mathrm{mg} \mathrm{ml}^{-1}$ with emulsification efficiency $\left(E_{24}\right)$ after $24 \mathrm{~h}$ of $64 \%$ against kerosene oil. The cell bound BS was partially purified by silica gel column chromatography and found as glycolipid. The gas chromatography and mass spectroscopy data revealed the fatty acid as hexadecanoic acid. Xylose was determined as hydrophilic moiety. The $\mathrm{BS}$ was found to be stable to $\mathrm{pH}$ changes over a range of 4.0-12.0, being most effective at $\mathrm{pH} 7$ and showed no apparent loss of surface tension and emulsification efficiency after heat treatment at $120^{\circ} \mathrm{C}$ for $15 \mathrm{~min}$. The outcomes of cellular toxicity showed lower toxicity of BS in comparison to SDS and rhamnolipids. Current study confirmed the preventive anti-adhesion activity of BS. These amphiphilic molecules, interferes with the microbial adhesion and found to be least cytotoxic with cellular compatibility with mouse fibroblasts cells.
\end{abstract}

Keywords: Biosurfactant; Glycolipids; Probiotic; Lactic acid bacteria; Cytotoxicity

\section{Introduction}

Microbial surfactants are amphiphilic molecules which exhibit high surface activity and emulsifying properties. Microbial surfactants can be potential substitutes to chemical surfactants due to their stability under extreme conditions, structural diversity, low toxicity and biodegradability. BS are commonly employed in crude oil recovery (Banat et al. 2010) hydrocarbon degradation in soil (Nitschke et al. 2011; Saharan et al. 2011; Sharma and Singh 2014; Saharan et al. 2014) heavy metals removal from contaminated soil (Juwarkar et al. 2007) and hydrocarbon biodegradation in aquatic environment (Khire 2010). Surface interactions are mediated by the amphiphilic nature of the molecules consists of hydrophilic regions (acid, peptide cations, or anions, mono-, di- or polysaccharides) and hydrophobic regions (unsaturated or saturated hydrocarbon chains or fatty acids), which allow them to act as surfactants at the interfaces (Banat et al. 2010; Myers 2005). The availability of commercially produced BS are limited to surfactin, sophorolipids

\footnotetext{
* Correspondence: baljeet.kuk@gmail.com

'Department of Microbiology, Kurukshetra University, Kurukshetra 136119 , INDIA

Full list of author information is available at the end of the article
}

and rhamnolipids (Saharan et al. 2011). Lactobacillus spp. are potent BS producing microorganism predominately found in the gastrointestinal microflora of human and animals. BS derived from lactic acid bacteria contributes to their high attributes of prevention of bacterial infections in the human body (Gudina et al. 2011). A number of studies reported the potential of lactobacilli as BS producers and their significant role in public health (Velraeds et al. 1996; Heinemann et al. 2000; Rodrigues et al. 2004; Servin 2004; Rodrigues et al. 2006a, b; Falagas and Makris 2009; Augustine et al. 2010; Saravanakumari and Mani 2010; Thavasi et al. 2011; Gudina et al. 2011; Saharan et al. 2011; Rodriguez-Pazo et al. 2013; Moldes et al. 2013). Silicone rubber material is extensively used in sophisticated medical instruments and voice prostheses due to its ease of casting and exceptional mechanical properties. But the hydrophobic silicone rubber surfaces becomes colonized with biofilm forming pathogens including bacterial and yeast strains (Monteiro et al. 2011). Hydrophobic silicone rubber surface becomes colonized by a variety of bacterial and yeast strains (Neu et al. 1990). Laryngectomized patient encountered problems associated with biofilms formation on silicone rubber surfaces. Biofilm formation associated with severe 
problems once the biofilm formation has prolonged. Blocking and leakage due to biofilm formation affect the function of the device and need to be change regularly (Busscher and Van der Mei 1997). Application of BS to a surface modifies its hydrophobicity, interferes microbial adhesion and desorption processes; in that sense, the production of BS by probiotic bacteria in vivo can be considered as a defense against other colonizing food borne pathogens (Van Hoogmoed et al. 2000; Nitschke et al. 2009). BS coating decreases the contact angle of silicone surface and it becomes hydrophilic (Rodrigues et al. 2006a). BS derived by lactic acid bacteria impaired biofilm formations on silicone rubber and other biomedical instruments surfaces (Velraeds et al. 1996; Busscher et al. 1997; Velraeds et al. 1997; Velraeds et al. 2000; Van der Mei et al. 2000; Rodrigues et al. 2004; Walencka et al. 2008; Fracchia et al. 2010; Gudina et al. 2011). The present work describes the production of novel BS produced by LAB isolates from butter milk. The current study also includes functional, structural and cytotoxic characterization of the BS produced. As far as literature surveyed, this is the first compilation of data on BS production from E. faecium and its structural attributes.

\section{Materials and methods Isolation of LAB}

BS producing $L A B$ was isolated from indigenous buttermilk sample by enrichment in $100 \mathrm{ml}$ of sterile minimal media (MM) in Erlenmeyer flask with $1 \%$ paraffin oil as carbon source. The suspension was incubated at $37^{\circ} \mathrm{C}$ for $48 \mathrm{~h}$. After incubation the inoculum from the culture flasks was sub cultured on deMan Rogosa and Sharpe (MRS) agar medium contains (20 g D-Glucose $\mathrm{l}^{-1}, 10 \mathrm{~g}$ Peptone $\mathrm{l}^{-1}$, $10 \mathrm{~g}$ Beef extract $\mathrm{l}^{-1}, 5 \mathrm{~g}$ Yeast extract $\mathrm{l}^{-1}$, 2 g Di-potassium phosphate $\mathrm{l}^{-1}, 2 \mathrm{~g}$ Tri-ammonium hydrogen citrate $\mathrm{l}^{-1}, 5 \mathrm{~g}$ Sodium acetate $\mathrm{l}^{-1}, 0.2 \mathrm{~g}$ Magnesium sulphate $\mathrm{l}^{-1}$, Manganese sulphate $\mathrm{l}^{-1}$ and $1 \mathrm{~g}$ Tween-80 $\mathrm{l}^{-1}$ ). LAB were stored at $-20^{\circ} \mathrm{C}$ in MRS broth containing $20 \%(\mathrm{v} / \mathrm{v})$ glycerol stock as master stock until they were used in current study.

\section{Screening for BS production}

$\mathrm{BS}$ production was examined with various methods i.e. drop collapse (Morikawa et al. 1993), emulsification index (Youssef et al. 2004) and surface tension (ST) measurement after $72 \mathrm{~h}$ of growth.

\section{Measurement of surface tension and CMC determination}

ST is an indicator of washability, wetting, and other surface related properties of any surfactant. ST of supernatant was measured by the De Nouy ring method, using a tensiometer equipped with a $1.9 \mathrm{~cm}$ platinum ring at room temperature (Lauda, Germany). ST of cell-bound biosurfactant was determined by measuring directly the ST of cell bound biosurfactant. Briefly, LAB cells were recovered at the end of experiment by centrifugation $\left(10,000 \mathrm{~g}, 10 \mathrm{~min}\right.$, and $\left.4^{\circ} \mathrm{C}\right)$, washed twice in demineralized water and resuspended in Phosphate buffer saline (PBS, pH 7.2) with gentle stirring for $2 \mathrm{~h}$. The sterile PBS was used as a control. The Instrument was calibrated twice by measuring ST of distilled water. The critical micelle concentration (CMC) was also determined by measuring the surface tension of serially diluted BS. The BS solution was prepared and diluted using Tris-HCl buffer, pH 8 (Faria et al. 2011). All the measurements were observed in triplicates.

\section{Taxonomic identification \\ Colony PCR}

Colony PCR was performed for taxonomic identification of the LAB isolate (Sheu et al. 2000). Briefly, the optimized colony PCR reaction mixture contained $1 \mathrm{X}$ PCR amplification buffer $\left(20 \mathrm{mM}\left(\mathrm{NH}_{4}\right)_{2} \mathrm{SO}_{4}, 72.5 \mathrm{mM}\right.$ Tris/ $\mathrm{HCl}, 0.1 \%$ Tween 20, pH 9.0), $2.5 \mathrm{mM} \mathrm{MgCl}_{2}, 200 \mu \mathrm{M}$ of each deoxynucleotide triphosphate, $2.5 \mu \mathrm{M}$ of each primer 27f (5-AGAGTTTGATCMTGGCTCAG-3) and 1385r (3-AATTCAAATTTAATTTCTTTCC-5), $1.25 \mathrm{U}$ DNA polymerase in $50 \mu \mathrm{l}$ PCR reaction mixture. Approximately $1 \mathrm{~mm}$ diameter colonies were picked up with sterilized toothpick and directly transferred to the PCR tube as DNA templates. The thermal cycle programme, run on a thermocycler PCR system (Eppendorf, Germany) consisted of one cycle of $94^{\circ} \mathrm{C}$ for $10 \mathrm{~min}, 51^{\circ} \mathrm{C}$ for $2 \mathrm{~min}$, $72^{\circ} \mathrm{C}$ for $2 \mathrm{~min}$, and 35 cycles of $94^{\circ} \mathrm{C}$ for $20 \mathrm{~s}, 57^{\circ} \mathrm{C}$ for $45 \mathrm{~s}$ (decreased by $1 \mathrm{~s}$ per cycle), $72^{\circ} \mathrm{C}$ for $1 \mathrm{~min}$, and then incubation at $72^{\circ} \mathrm{C}$ for $5 \mathrm{~min}$, and a final incubation at $4^{\circ} \mathrm{C}$. PCR-amplified DNA fragments were observed on $1.3 \%$ agarose gel in TAE buffer $(0.04 \mathrm{M}$ Tris acetate, $0.02 \mathrm{M}$ acetic acid, $0.001 \mathrm{M}$ EDTA), containing $1 \mathrm{~g} / \mathrm{ml}$ of SYBR green. Briefly, $10 \mu \mathrm{l}$ of each amplification mixture and the molecular mass marker were separated on agarose gel electrophoresis. The amplified DNA fragments were visualized by UV illumination. The $16 \mathrm{~S}$ rRNA gene sequence obtained from the isolate was compared with other bacterial sequences by using NCBI mega BLAST (http://blast.ncbi.nlm.nih.gov/Blast.cgi) for their pair wise identities. Multiple alignments of these sequences were carried out by Clustal W of EBI (www.ebi.ac.uk/ cgi-bin/clustalw/) with 0.5 transition weight. Nucleotide composition of each aligned sequence was determined by DNA baser software package (http://www.dnabaser.com/) and the $16 \mathrm{~S}$ rRNA sequence was deposited in GenBank.

\section{Production media and cultivation conditions}

For BS production in shake flask condition, $250 \mathrm{ml}$ of MRS-Lac (glucose was replaced by lactose) broth ( $\mathrm{pH}$ 6.2) was inoculated with $1 \%(\mathrm{v} / \mathrm{v})$ of pre-culture and incubated 
for $72 \mathrm{~h}$ at $37^{\circ} \mathrm{C}$ ). After $72 \mathrm{~h}$, cells were harvested by centrifugation $\left(10,000 \mathrm{~g}, 10 \mathrm{~min}, 4^{\circ} \mathrm{C}\right)$, washed twice and resuspended in $100 \mathrm{ml}$ of PBS (Rodrigues et al. 2006b). The suspension was kept at room temperature for overnight with gentle stirring for the release of cell-bound BS. Cell free suspension was filtered through a $0.22 \mu \mathrm{m}$ pore size filter (Axiva, India). The suspension was dialyzed against demineralized water at $4^{\circ} \mathrm{C}$ in a dialysis membrane (molecular weight cutoff 6,000-8,000 Dalton, Himedia, India) and freeze dried.

\section{Purification of BS}

The cell-bound BS was partially purified in silica gel (60-120 mesh) column eluted with gradient of chloroform and methanol ranging from 20:1 to 2:1 (v/v). The fractions were pooled after TLC analysis and solvent was evaporated.

\section{Structural characterization \\ Thin layer chromatography (TLC)}

The composition of the cell-bound partially purified BS was determined by TLC followed by post chromatographic detection. Briefly, $4 \mathrm{ml}$ of PBS extract was extracted twice with ethyl acetate 1:1.25 (Rankem, India). Upper phase was extracted two times with ethyl acetate and the ethyl acetate was allowed to evaporate at room temperature (Syldatk et al. 1985; Schenk et al. 1995; Hormann et al. 2010). $1 \mathrm{ml}$ aliquot of BS extract was concentrated and separated on a precoated silica gel plate (Merck, India) using chloroform/methanol/glacial acetic acid $(65: 15: 2 \mathrm{v} / \mathrm{v})$ as mobile phase. The polysaccharides moities were stained with Syldatk reagents (anisaldehyde: sulfuric acid: glacial acetic acid 0.5:1:50), whereas the fatty acid moieties were stained with ammonium molybdate/cerium sulfate $(0.42 \%$, w/v; ammonium molybdate and $0.2 \%, \mathrm{w} / \mathrm{v}$, cerium (IV) sulfate in $6.2 \%$ sulfuric acid). Plates were heated at $120^{\circ} \mathrm{C}$ for $10 \mathrm{~min}$. The chromatograms of the BS were compared with the TLC pattern of a standard mixture of di-rhamnolipids of Pseudomonas aeruginosa which was prepared from Jeneil JBR 425 (Jeneil Biosurfactants Company, Saukville, United States).

\section{Ionic property of BS}

The ionic property of cell bound BS was determined by using agar well diffusion method (Meylheuc et al. 2001). Briefly, 3 uniformly spaced wells were made on a soft agar (1\%) plate, central well was filled with $10 \mu \mathrm{l}$ of BS. Either sides of wells were filled with anionic compound (Sodium dodecyl sulfate, $20 \mathrm{mM}$ ) and cationic compound (Cetyl trimethyl ammonium bromide (CTAB), $20 \mathrm{mM}$ ). Plates were incubated at $25^{\circ} \mathrm{C}$ for $24 \mathrm{~h}$ and observed for the precipitation lines.
Fourier transform infrared spectroscopy (FTIR) and Nuclear magnetic resonance (NMR) spectroscopy

Molecular components of partially purified cell bound BS was elucidated using FTIR spectroscopy by scanning it in the range of $4000-400 \mathrm{~cm}^{-1}$ at a resolution of $4 \mathrm{~cm}^{-1}$ with resolution of 2 wavenumbers per wavenumber. (Model-ABB \& MB-3000). The 1-3 mg BS was dissolved in $100 \% \mathrm{CDCl}_{3}$ and ${ }^{13} \mathrm{CNMR}$ analysis was carried out using a Bruker Av II-400 spectrometer. Both proton and carbon NMR chemical shifts were stated in ppm relative to the solvent shift as chemical standard. Peaks were compared and predicted with the data reported previously.

\section{Liquid chromatography (UPLC) and mass spectroscopy}

Aliquots of the partially purified BS was dissolved in methanol to obtain $1 \mathrm{mg} \mathrm{ml}^{-1}$ solution. Waters (UPLC) system equipped with quaternary gradient pump, auto sampler and a Photo diode detector (PDA, 2996) were used in present study. Separation was performed with C18 column $(1.7 \mu \mathrm{m} \times 2.1 \mu \mathrm{m} \times 100 \mathrm{~mm})$ at column oven temperature $40^{\circ} \mathrm{C}$. A multistep linear gradient composed of eluent A (Water $+0.1 \%$ trifluoroacetic acid) and eluent $\mathrm{B}$ (Acetonitrile $+0.1 \%$ trifluoroacetic acid) was applied. The auto sampler temperature was maintained at $10^{\circ} \mathrm{C} .10 \mu \mathrm{l}$ of sample solution was injected. From $0-13 \mathrm{~min}$ a linear gradient was applied from the mixture A: B $(70: 30, \mathrm{v} / \mathrm{v})$ to A: B $(0: 100 \mathrm{v} / \mathrm{v})$. A plateau of $100 \%$ eluent $B$ from $13 \mathrm{~min}$ to $15 \mathrm{~min}$ was set before going back to $70 \%$ eluent $\mathrm{A}$ from $15 \mathrm{~min}$ to $16 \mathrm{~min}$. Flow rate of mobile phase was $0.3 \mathrm{ml} / \mathrm{min}$. The LC system was coupled with a Waters mass spectrometer with an atmospheric pressure electroscopy interface. The ESI source was set in positive and negative ionization mode. Nitrogen gas was used as nebulizer gas and Helium gas a collision gas (Janek et al. 2013).

\section{Gas chromatography and mass spectroscopy (GC-MS) Fatty acids analysis}

The sample was reconfirmed on gas chromatograph-mass spectrometer system equipped with a VF-5MS column (Thermo Scientific TSQ 8000). Briefly, the initial column temperature was $100^{\circ} \mathrm{C}$ for $1 \mathrm{~min}$, then ramped at

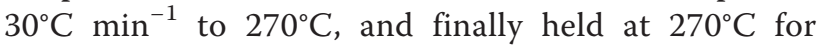
$10 \mathrm{~min}$. The temperatures of the transfer line, ion trap, and quadrupole were 280,230 , and $150^{\circ} \mathrm{C}$, respectively. The inlet temperature was $270^{\circ} \mathrm{C}$, and a $100 \mu \mathrm{L}$ sample was injected. The flow rate of the carrier gas (helium) was $1.0 \mathrm{~mL} \mathrm{~min}^{-1}$.

\section{Thermal gravimetric (TG) analysis}

TG analyses of freeze dried partially purified BS were carried out with Mettler Toledo TGA/SDTA system (Greifensee, Switzerland). Briefly, 5-8 mg of lyophilized 
sample was loaded in a platinum pan and its energy level was scanned in the ranges of $30-480^{\circ} \mathrm{C}$ and $30-450^{\circ} \mathrm{C}$ respectively under a nitrogen atmosphere, with a temperature gradient of $10^{\circ} \mathrm{C} \mathrm{min}^{-1}$. Analysis was performed under gradual increase in temperature, plotting the weight percentage and heat flow against temperature respectively.

\section{Study of BS stability}

Stability studies were performed using the cell free broth obtained by centrifugation at $8000 \times \mathrm{g}$ for $20 \mathrm{~min} .10 \mathrm{ml}$ of BS suspension ( $25 \mathrm{mg} \mathrm{ml}^{-1}$ ) was kept at $0,5,15,25$, $50,75,100$, and $125^{\circ} \mathrm{C}$ for $30 \mathrm{~min}$, cooled to room temperature; the surface tension and emulsification index were determined. To elucidate the $\mathrm{pH}$ stability of BS, the sample was adjusted to different values (5.0-12.0) with $1 \mathrm{M} \mathrm{NaOH}$ and $1 \mathrm{M} \mathrm{HCl}$, and the same aforesaid measurements were performed. All the assay were carried out in triplicates.

\section{Biofilm inhibition assay on silicone tubes}

The biofilm forming pathogenic strains of Escherichia coli ATCC 25922, Staphylococcus aureus ATCC 6358P, Pseudomonas aeruginosa ATCC 15442, Bacillus cereus ATCC 11770, Listeria monocytogenes MTCC 1143 and C. albicans MTCC 183 were used as indicators in the biofilm inhibition assay on silicone tubes. Briefly, $10 \mu \mathrm{l}$ volumes of overnight bacterial cultures were added into $1000 \mu \mathrm{l}$ of fresh Luria broth (LB) medium. The same volume of $C$. albicans was also added into $1000 \mu \mathrm{l}$ of fresh YPD medium. $1000 \mu$ l cell-bound partially purified BS (50 mg ml $\mathrm{m}^{-1}$ ) was added (final concentration of BS in solution was $25 \mathrm{mg} \mathrm{ml}^{-1}$ ) in LB and YPD medium. Furthermore, $4 \mathrm{~cm}$ long pieces of sterile silicone tubes (Himedia, India) incubated with medium amended with $\mathrm{BS}$ for $24 \mathrm{~h}$ at $37^{\circ} \mathrm{C}$. After incubation, silicone tubes were removed and washed twice with distilled water. Air dried silicone tubes were further stained with $0.1 \%$ crystal violet solution for $20 \mathrm{~min}$. The stained silicone tubes were washed twice with distilled water and allowed to dry at room temperature for 30 min (Janek et al. 2013).

\section{Pre-adhesion treatment on polystyrene surface with BS}

The antiadhesive activity of the crude BS derived from isolate MRTL 9 against several biofilm forming pathogen strains was quantified according to the procedure described by Heinemann et al. (2000). Briefly, the wells of a sterile 96 well flat bottomed plastic tissue culture plate (Himedia, India) were filled with $200 \mu \mathrm{l}$ of the crude biosurfactant. The plate was incubated for $18 \mathrm{~h}$ at $4^{\circ} \mathrm{C}$ and subsequently washed twice with PBS. Control wells contained PBS buffer only. An aliquot of $200 \mu \mathrm{l}$ of a washed bacterial or yeast suspension was added and incubated in the wells for $4 \mathrm{~h}$ at $4^{\circ} \mathrm{C}$. Unattached microbial cells were removed by washing the wells three times with PBS. The adherent cells were fixed with $200 \mu \mathrm{l}$ of methanol (Himedia, India) per well. Then the plates were stained for $5 \mathrm{~min}$ with $200 \mu \mathrm{l}$ of $2 \%$ crystal violet solution. Excess stain was washed out by placing the plate under running tap water. The dye bound to the adherent micro-organisms was resolubilized with $200 \mu \mathrm{l}$ of $33 \%(\mathrm{v} / \mathrm{v})$ glacial acetic acid (Himedia, India) and the absorbance of each well was measured at $600 \mathrm{~nm}$. The inhibition percentages at different biosurfactant concentrations for each microorganism were calculated as:

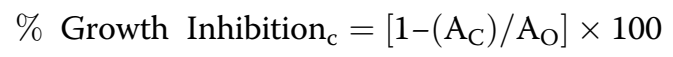

Where Ac represents the absorbance of the well with a biosurfactant concentration $\mathrm{c}$ and $\mathrm{A}_{0}$ the absorbance of the control well.

\section{Cytotoxicity assessment}

The cytotoxicity of BS was evaluated on mouse fibroblast (ATCC L929) cell line (Cochis et al. 2012). The cells were cultured in Dulbecco Modified Eagle Medium (DMEM) at $37^{\circ} \mathrm{C}$ in $5 \% \mathrm{CO}_{2}$ atmosphere. A standardized quantity of cells $\left(1 \times 10^{4}\right)$ was inoculated in $100 \mu \mathrm{l}$ of DMEM in 96 well culture plates and incubated for stabilization for $24 \mathrm{~h}$ before the treatment. The stock solution of BS was prepared in DMSO (99.9\%) at concentration of $10 \mu \mathrm{g} / 1 \mu \mathrm{l}$. The final quantities of BS was added $25 \mu \mathrm{g}, 12.5 \mu \mathrm{g}$ and $6.25 \mu \mathrm{g}$ and incubated for $24 \mathrm{~h}$ at $37^{\circ} \mathrm{C}$ in $5 \% \mathrm{CO}_{2}$ atmosphere. After $24 \mathrm{~h}, 15 \mu \mathrm{l}$ dye solution from the Cell Titre $96^{\circ}$ non-radioactivity cell proliferation assay kit (Promega, USA) was added in to the wells and kept for $4 \mathrm{~h}$ incubation as per the recommendation. $100 \mu \mathrm{l}$ stopping solution was added in all the wells and incubated overnight to dissolve formazan product to get uniform readings. The absorbance was recorded at $570 \mathrm{~nm}$ in microplate spectrophotometer (SPECTRAmax, Molecular devices, USA). The DMSO used as solvent was taken as negative control in the assay (amount equal to prepare BS dilution). To estimate the cytotoxicity of biosurfactant, microbially originated Rhamnolipid (25 mg ml $\mathrm{ml}^{-1}$ ) and Sodium dodecyl sulfate $\left(25 \mathrm{mg} \mathrm{ml}^{-1}\right.$ ) were used as positive and negative controls respectively. All the data is analyzed and plotted in advance graphic software Slide Write Plus $^{\mathrm{TM}}$ v.6.

\section{Results and discussion Screening for BS production}

Initially the LAB isolate was screened for ability to produce surface active agents. The selection of BS producing strain was a two stages selection process. Primarily the isolate was screened for their ability to produce BS 
using drop collapse assay. The flattened drop of PBS containing BS over the paraffin liquid coated surface confirmed the presence of BS. In addition to the surface activity, efficient emulsification property is critical for promising BS and its applications (Banat et al. 2000). Probiotic strain of $L$. acidophilus was isolated and screened for surface active agents using drop collapse assay (Tahmourespour et al. 2011). The emulsification ability of BS was assayed and maximum emulsification activity was found with Kerosene oil $\left(E_{24}=64 \%\right)$. Drop collapse method and emulsification index are semiquantified methods, so in need to quantify significant reduction in ST was measured by Tensiometer. The potential of a microbial surfactant is determined by its capability to reduce the surface tension of production medium. A potent BS can decrease the ST of distill water from 72.0 to $35.0 \mathrm{mN} \mathrm{m}^{-1}$ (Busscher et al. 1994; Mulligan 2005).

The BS produced by strain MRTL9 showed a significant reduction in ST of PBS extract from 72 to $40.2 \mathrm{mN} \mathrm{m}^{-1}$. Various LAB strains were reported as BS producer on the basis of their ability to reduce surface tension of production media. A significant reduction in surface tension was reported while working with different strains of $L$. casei and Bifidobacterium from 72 to $35.5 \mathrm{mN} \mathrm{m}^{-1}$ (Golek et al. 2009). Whereas, Streptococcus thermophilus A and Lactococcus lactis 53 reduced surface tension around 36.0$37.0 \mathrm{mN} \mathrm{m}^{-1}$ (Rodrigues et al. 2004). In addition to the ST, CMC of the purified BS was found to be approximately $2.25 \mathrm{mg} \mathrm{ml}^{-1}$ in Tris-HCl buffer, $\mathrm{pH}$ 8. The flattened drop collapse, significant ST reduction and potent emulsification index decisively confirmed the biosurfactant production by the strain.

\section{Taxonomic identification}

Isolate MRTL 9 was taxonomically identified using $16 \mathrm{~S}$ rRNA sequencing using universal primers. Genomic DNA was directly amplified by colony PCR using universal $16 \mathrm{~S}$ rRNA primers. Taxonomic affiliation of the isolates was retrieved from GenBank. The blast algorithm (http://blast.ncbi.nlm.nih.gov/Blast.cgi) was used to determine the most related sequence relatives in the GenBank database. Isolate was identified as Enterococcus faecium after sequence alignment using BLAST algorithms. Nucleotide sequences has been deposited in the NCBI GenBank database (http://www.ncbi.nlm. nih.gov/) with the accession number KC456369. Incidence of $E$. faecium were also reported earlier from various fermented foods with beneficiary probiotic attributes (Albesharat et al. 2011; Grosu-Tudor et al. 2013).

\section{Production and purification of BS}

The production of BS was carried out by inoculating with $1 \%$ overnight pre culture at $37^{\circ} \mathrm{C}$ in a rotary shaker for $72 \mathrm{~h}$. After incubation, ST of the cell bound BS in PBS reduced to $40.2 \mathrm{mN} \mathrm{m}^{-1}$ from $72 \mathrm{mN} \mathrm{m}^{-1}$. ST of the production media was reduced with the course of incubation time (Figure 1). The significant decrease of ST established the production of BS by the E. faecium MRTL 9. Maximal ST reduction was observed at late

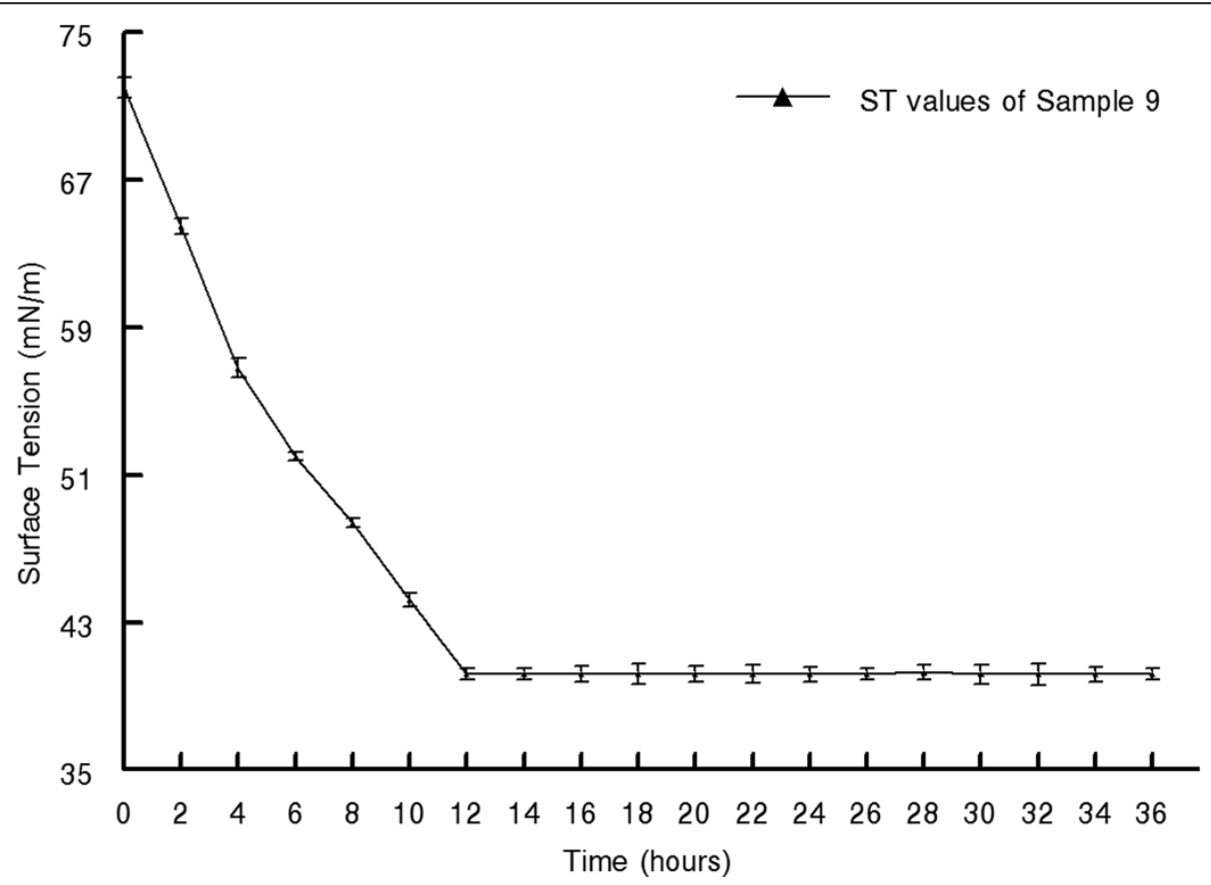

Figure 1 Decrease of surface tension with time by cell bound BS. 
logarithmic and early stationary phase of cell growth. Reduction in ST during the logarithmic and stationary phase has been reported and confirmed the production of BS (Oliveira and Garcia-Cruz 2013; Madhu and Prapulla 2014). BS was extracted twice with equal volume of ethyl acetate; crude BS (brown in color) was obtained and partially purified using column chromatography (Silica gel; 60-120 mesh size). Fraction with highest activity were pooled and analyzed by different thin layer chromatography (TLC) with post chromatographic detections.

\section{Characterization of BS}

TLC is the most extensively studied method for structural determination of BS (Carrillo et al. 1996; Mohebali et al. 2007). BS was initially characterized by TLC followed by post chromatographic detection. Developed silica plate when sprayed with Syldatk reagent produced a dark red spot indicating the presence of sugar moieties. Further, replica plate was sprayed with ammonium molybedate produced gives a dark blue spot indicated the presence of lipid moiety. No amino acid residues were detected while stained with Ninhydrin reagent. The above results of TLC characterization confirmed the presence of the glycolipid BS. Generally glycolipids are carbohydrates in amalgamation with long-chain aliphatic or hydroxy aliphatic acids (Lang 2002). A glycolipid like moiety was reported extremely surface active, reducing the surface tension of water to $35 \mathrm{mN} \mathrm{m}^{-1}$ (Velraeds et al. 1997; Sauvageau et al. 2012). Partially purified cell bound BS was appeared as crystalline dirty white powder. The BS formed white precipitation line between sample well and cationic compounds CTAB with barium chloride. The BS derived from E. faecium was confirmed as an anionic BS. Generally BS produced from other LAB were found as anionic surfactants. Xylolipid produced by Lactococcus lactis was also reported anionic in nature (Saravanakumari and Mani 2010).

\section{FTIR analysis}

Several reports have been published on BS produced by $\mathrm{LAB}$ but inadequate information about their chemical composition is known. LAB derived BS were initially characterized as multicomponent mixtures consisting of protein fractions, polysaccharides and phosphate groups (Velraeds et al. 1996; Rodrigues et al. 2004; Thavasi et al. 2008; Falagas and Makris 2009; Sauvageau et al. 2012; Schippers et al. 2000). BS derived from E. faecium MRTL 9 in stationary growth phase was biochemically characterized as glycolipid (Figure 2, Table 1). Analysis of FTIR spectrum of BS sample revealed the composition as lipid and polysaccharide fractions. The molecular composition of BS revealed that most prominent adsorption bands were located at $3009 \mathrm{~cm}^{-1}, 2855 \mathrm{~cm}^{-1}$ and $2955 \mathrm{~cm}^{-1}\left(\mathrm{C}-\mathrm{H}\right.$ stretching bands of $\mathrm{CH}_{2}$ and $\mathrm{CH}_{3}$ groups), $1674 \mathrm{~cm}^{-1}$ ( $\mathrm{C}=\mathrm{O}$ stretching vibrations of the carbonyl groups), $1103 \mathrm{~cm}^{-1}$ (C-O stretching bands; formed between carbon atoms and hydroxyl groups in the chemical structures) and $771 \mathrm{~cm}^{-1}\left(\mathrm{CH}_{2}\right.$ group) which prominently confirmed the presence of glycolipid type of BS (Thavasi et al. 2008 and Rodrigues et al. 2006b). According to FTIR spectrum obtained, the BS is composed of carbohydrates and lipid. The hydrophobic chain of BS is composed of lipid and hydrophilic part is mainly composed of sugar. Comparison of the spectra obtained revealed that the BS is closely similar to Xylolipid (glycolipid) reported earlier from different LAB strains (Thavasi et al. 2008, 2011; Saravanakumari and Mani 2010).

\section{NMR spectroscopy}

Furthermore, the spatial arrangement of proton and carbon in bio-molecule has been carried out by ${ }^{1} \mathrm{H}$ NMR and ${ }^{13} \mathrm{C}$ NMR spectroscopy. The typical chemical shifts were pointed out that the BS has the molecular structure closely resembles to glycolipid (Figure 3, Table 2). The chemical shifts were harmonized with those of previous

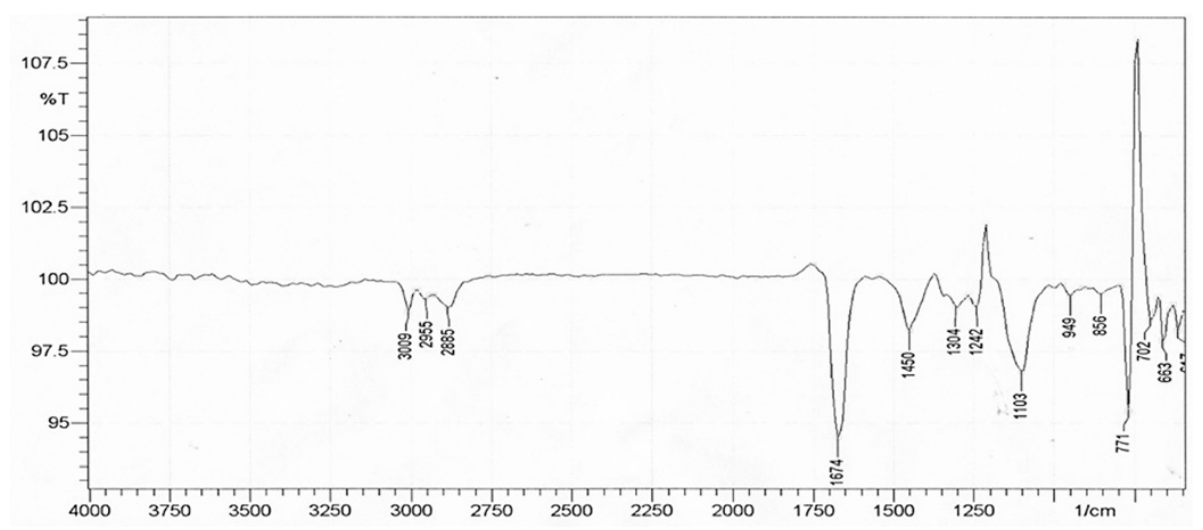

Figure 2 FTIR spectra of BS produced by E. faecium MRTL9. 
Table 1 Absorbance maxima of IR spectra and functional groups detected in the BS produced by Enterococcus faecium

\begin{tabular}{lc}
\hline Absorbance range $\left(\mathbf{c m}^{\mathbf{- 1}}\right)$ & Functional groups detected \\
\hline $3000-3600$ & $\mathrm{OH}$ stretching, typical polysaccharides \\
$2900-2950$ & $\mathrm{C}-\mathrm{H}$ (stretching) groups $\mathrm{CH}_{2}$ and $\mathrm{CH}_{3}$ \\
1725,1675 & $\mathrm{C}=\mathrm{O}$ (stretching of carbonyl group) \\
$1400-1460$ & $\mathrm{C}=\mathrm{H}$ stretching \\
$1000-1300$ & $\mathrm{C}-\mathrm{O}$ sugar stretching \\
$675-1000$ & $\mathrm{C}-\mathrm{H}$ bending \\
\hline
\end{tabular}

reports of glycolipids. A number of peaks were observed in NMR due to the presence of sugar moieties and aliphatic fatty acids chains. The proton NMR spectra seems complex, however some distinguished peaks were present and their chemical shift was evaluated. The presence of chemical shift $(\delta)$ at $4.09 \mathrm{ppm}, 3.53 \mathrm{ppm}$, $3.53 \mathrm{ppm}, 2.35 \mathrm{ppm}, 3.72 \mathrm{ppm}$ and $3.52 \mathrm{ppm}$ indicated $\mathrm{C}_{1}, \mathrm{C}_{2}, \mathrm{C}_{3}, \mathrm{C}_{4}, \mathrm{C}_{5}, \mathrm{OCH}_{3}$ and $-\mathrm{COOH}$ groups respectively in proton NMR spectra. The presence of chemical shifts at $127.38 \mathrm{ppm}, 60 \mathrm{ppm}, 69.5 \mathrm{ppm}, 58.81 \mathrm{ppm}$, $53.51 \mathrm{ppm}$ and $170.79 \mathrm{ppm}$ were also depicted $\mathrm{C}_{1}, \mathrm{C}_{2}$, $\mathrm{C}_{3}, \mathrm{C}_{4}, \mathrm{C}_{5}, \mathrm{OCH}_{3}$ and $-\mathrm{COOH}$ groups respectively in carbon NMR spectra. Characteristic spectra peaks of NMR were also reported in Xylolipid from Lactococcus lactis (Saravanakumari and Mani 2010) and other closely related glycolipids (Henkel et al. 2012; Morita et al. 2012; Lotfabad et al. 2013; Desai and Banat 1997; Falagas and Makris 2009).

\section{UPLC MS analysis}

The molecular mass of the active compound was measured using UPLC/ESI-MS. A prominent peak with a retention time of $25.29 \%$ was observed. The liquid chromatography coupled with mass spectrum confirmed the presence of glycolipid type of BS possibly composed of
Table 2 Chemical shift assignment (NMR data) of BS produced by Enterococcus faecium MRTL9

\begin{tabular}{lcc}
\hline Assignment(s) & ${ }^{\mathbf{1}} \mathbf{H}$ NMR $(\mathbf{p p m})$ & ${ }^{\mathbf{1 3}} \mathbf{C}$ NMR $(\mathbf{p p m})$ \\
\hline $\mathrm{C}-1$ & 4.09 & 127.38 \\
$\mathrm{C}-2$ & 3.53 & $\sim 60$ \\
$\mathrm{C}-3$ & 3.53 & $\sim 60$ \\
$\mathrm{C}-4$ & 2.35 & 69.5 \\
$\mathrm{C}-5$ & $3.72,3.61$ & 58.81 \\
$\mathrm{OCH}_{3}$ & 3.52 & 53.51 \\
$\mathrm{COOH}$ & - & 170.79 \\
\hline
\end{tabular}

lipid and polysaccharide fractions. The possible predicted structure of separated product is close and similar to the glycolipid with hexadecanoic fatty acid chain.

\section{GC-MS analysis of fatty acids of methyl esters (FAME)}

The fatty acid composition of was BS analyzed by GC-MS and compared with the library data. It was found that BS mainly comprised of long chain fatty acids, mainly C-16 long fatty acids (Figure 4). The major fatty acid of BS produced was C-16 hexadecanoic fatty acid (86.6\%). Hexadecanoic acid was found as main fatty acid chains in various studies of glycolipids purified previously. Saravanakumari and Mani (2010) have isolated BS from L. lactis which also contains octadecanoic acid as a fatty acid chain associated with sugar moiety. Rhamnolipids are the extensively isolated glycolipids which are also composed of $\beta$-hydroxydecanoic acid molecules as branched fatty acids (Desai and Banat 1997). Palmitic acid and stearic acid were found major fatty acid type in cell bound biosurfactant produced by L. pentosus (Vecino et al. 2014). On the basis of FTIR, NMR (Proton and carbon) liquid and gas chromatography the structure of BS produced by E. faecium elucidated and predicted as Xylolipid with hydrophillic part as xylose sugar and hydrophobic part as $\beta$-hydroxydecanoic
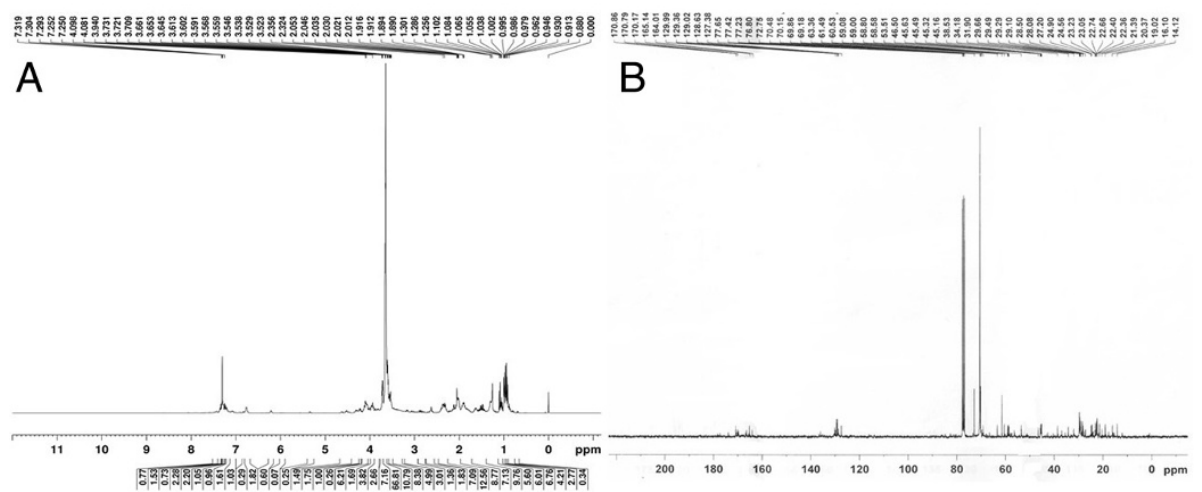

Figure $3{ }^{1} \mathrm{H}$ NMR (A) and ${ }^{13} \mathrm{C}$ NMR (B) spectrum of BS produced by Enterococcus faecium MRTL9. 


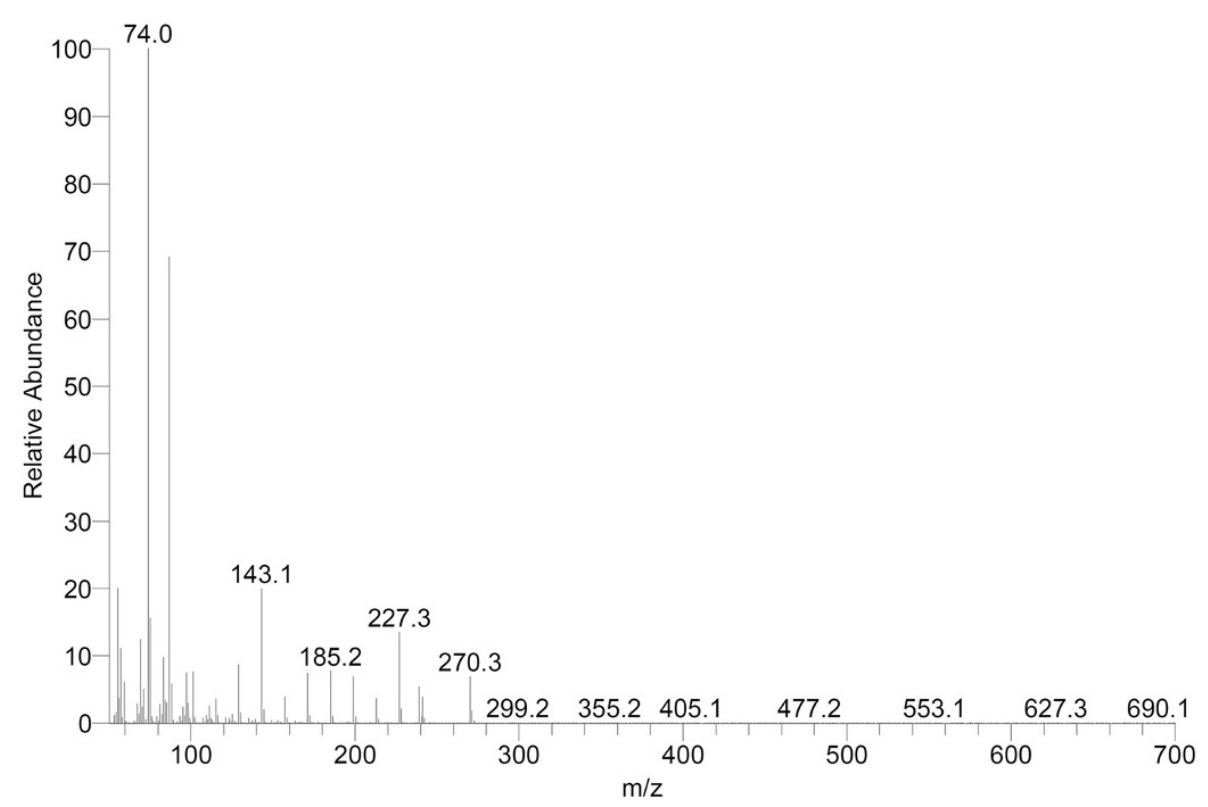

Figure 4 GCMS separation of BS produced by the E. faecium MRTL9 mainly showing peaks for hexadecanoic acid.

acid (Figure 5). There is one carboxyl group connected with the sugar and aliphatic hydrocarbon chain. The carboxyl group provided overall negative charge on the biomolecule which could be useful for binding and thus remediating divalent cations (Gutierrez et al. 2009)

\section{Thermal gravimetric analysis (TGA)}

Thermal stability of BS is a significant property for its commercial application at elevated ranges of temperature such as microbial enhanced oil recovery and food industries. Thermal degradation of BS was conducted by TG analysis. Approximately (1\%) of weight loss was observed with increase in initial temperature from 50 to $200^{\circ} \mathrm{C}$ possibly due to the loss of solvents and moisture molecules. Complete loss of BS was observed after $270^{\circ} \mathrm{C}$. Moisture release during heating of the polymer suggested that the polymer was not truly anhydrous. The degradation temperature (Td) was found to be $250^{\circ} \mathrm{C}$ determined from TGA curve (Figure 6). It was previously documented that the BS produced from alkalophilic strain of Klebsiella spp. showed maximum degradation at $350-400^{\circ} \mathrm{C}$ (Jain et al. 2013). Similar findings were also reported while working on the rhamnolipid produced by Pseudomonas aeruginosa MA01. The weight of polymer was dramatically lost around $290^{\circ} \mathrm{C}$ and continued gradually to decrease (Abbasi et al. 2012). BS isolated from the strain E. faecium showed similar thermal degradation behavior close to the glycolipids. BS produced by E. faecium was found to be thermostable. As molecular mass determined by mass spectroscopy confirmed that the BS isolated in the present study having similar molecular mass close to the glycolipid BS and also showed similar thermal degradation behavior.

\section{Stability of BS}

The application of BS is depends on their stability at extreme temperatures and $\mathrm{pH}$ range. The stability of $\mathrm{BS}$ was studied at different $\mathrm{pH}$, temperature and observed in conviction of effect on ST and emulsification index. Figures 7 and 8, present the effects of temperature and $\mathrm{pH}$ on surface tension and emulsification capacity of cell bound BS. In current study, partially purified BS retained activity over $\mathrm{pH}$ range from 6 to 10 with a minimal deviation in surface tension values. The $\mathrm{pH}$ values below and upper 7 showed minor increase in surface tension but found to be stable, the BS sustained activity even after treatment at $0-120^{\circ} \mathrm{C}$ for $30 \mathrm{~min}$. The effect of different $\mathrm{pH}$ and incubation at extreme temperature on<smiles>CO[C@H]1CO[C@@H](O[CH]CCCCCCCCCCCCCCCCC(=O)O)[C@H](O)[C@H](O)[C@@H]1O</smiles>

Figure 5 Composite structure of biosurfactant produced by E. faecium MRTL9 (Xylolipid). 


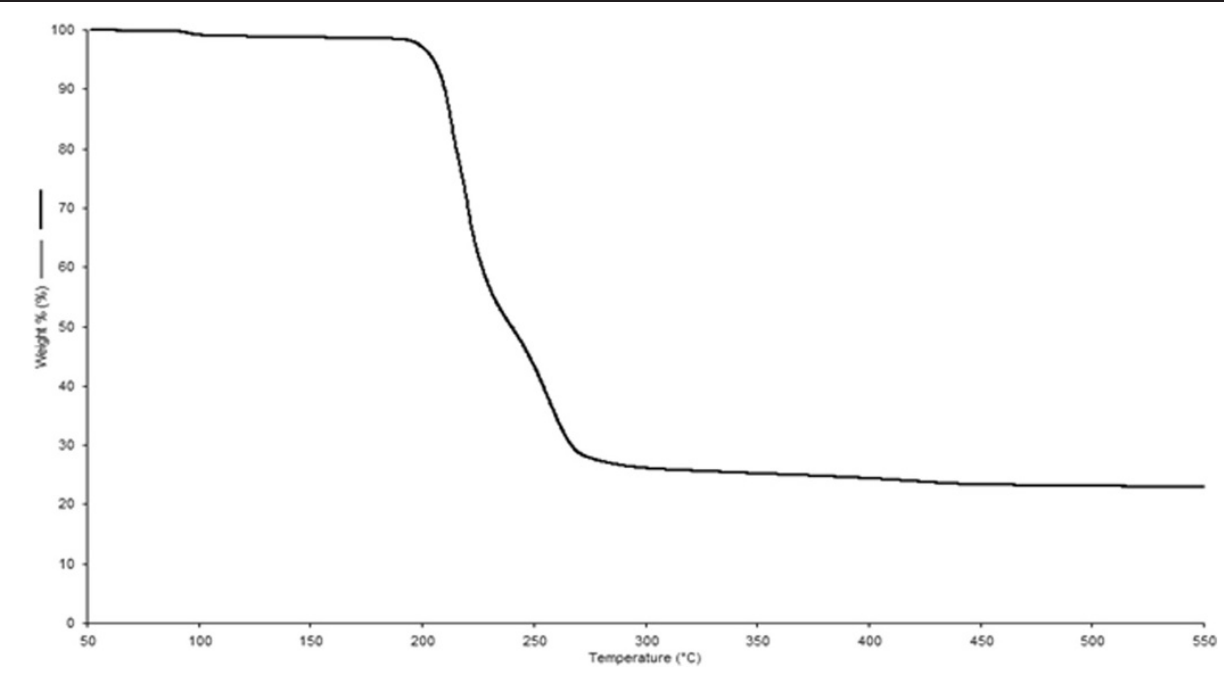

Figure 6 Thermal degradation analysis of BS produced by the E. faecium MRTL9.

surface tension and emulsification capacity were insignificant. Heat treatment (autoclaving at $120^{\circ} \mathrm{C}$ for $15 \mathrm{~min}$ ) on BS caused no appreciable changes in their surface and emulsifying activities (Desai and Banat 1997). Biosurfactant produced by Pseudomonas aeruginosa SP4 was also found stable isolated from petroleum contaminated soil (Pornsunthorntawee et al. 2008). BS from Candida lipolytica cultivated with industrial residue and a lipopeptides from Bacillus subtilis C9 cultivated with a carbohydrate substrate demonstrated similar stability behavior (Rufino et al. 2008). Lipopeptides of Bacillus subtilis also reported with stability at elevated temperature and different range of $\mathrm{pH}$ (Vaz et al. 2012). The BS was structurally stable and retained its surface activity even at the extreme $\mathrm{pH}$ and high temperature range. Stability of BS at high temperature also conferred in accordance with the results obtained after TG analysis.

\section{Biofilm removal on silicone tubes}

The biofilm developed by all the pathogenic strains was spread along the whole tube surface (Figure 9). Biofilm formation reduced significantly on silicone tube even at a low concentration of BS $\left(25 \mathrm{mg} \mathrm{ml}^{-1}\right)$. The pre incubation of silicone tubing with known concentration of BS was effective against all biofilm forming pathogens. Moderate anti-biofilm activity was observed against the yeast pathogenic strain C. albicans.

Falagas and Makris (2009) has proposed the application of BS isolated from probiotic LAB to patient care equipment's in hospitals to combat colonization by microorganisms responsible for nosocomial infections. BS derived from S. thermophiles A was found to be effective antiadhesive substance on silicon rubber and combat colonization of various microorganisms (Rodrigues et al. 2006). The number of bacterial cells adhering to the silicone rubber with preadsorbed BS reduced by $89 \%$ and $97 \%$ by two

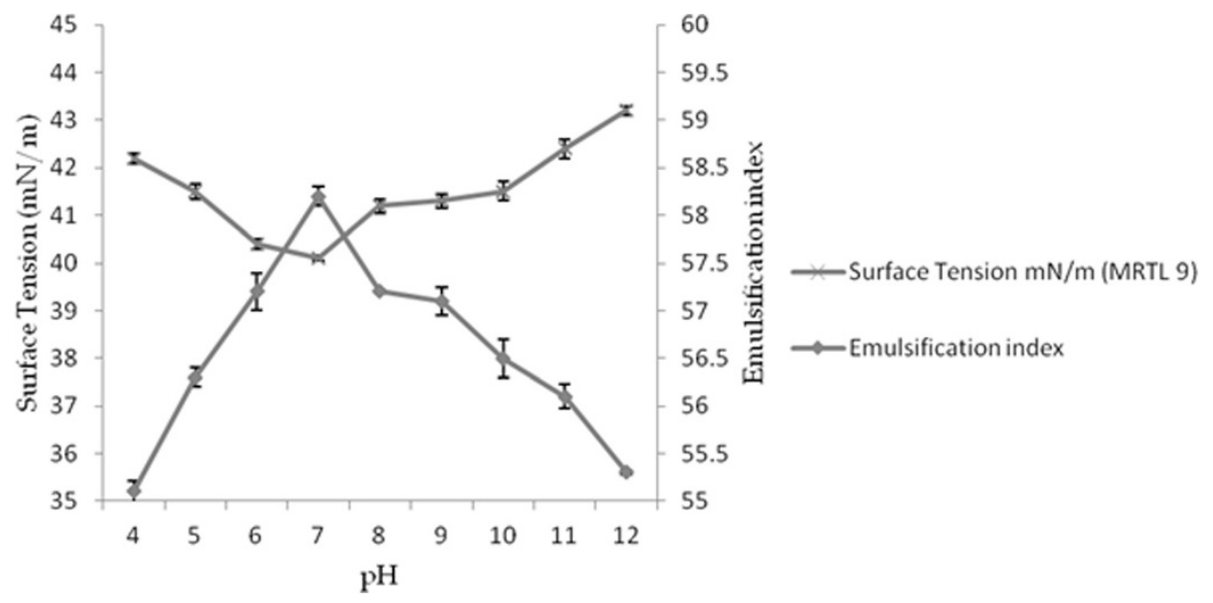

Figure 7 Effect of $\mathrm{pH}$ on the surface tension of the cell-bound partially purified BS isolated from E. faecium MRTL9. 


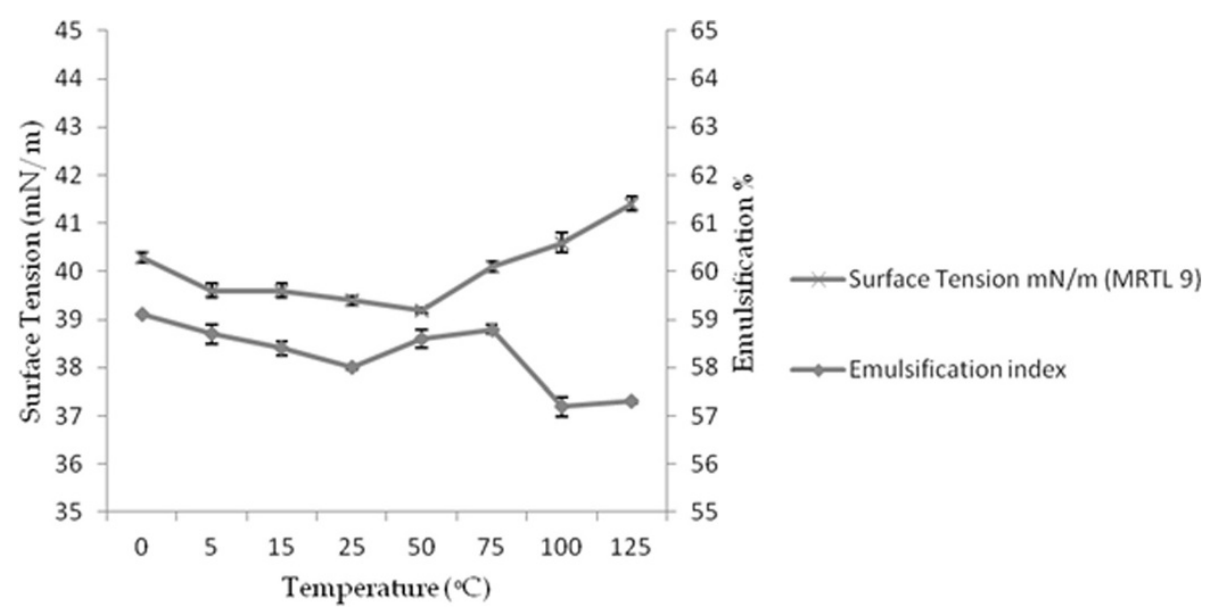

Figure 8 Effect of temperature on the surface tension of the cell-bound partially purified BS isolated from E. faecium MRTL9.

strains after $4 \mathrm{~h}$ incubation. BS with a concentration of $25 \mathrm{mg} \mathrm{ml}^{-1}$, was able to reduce $S$. aureus, S. epidermidis and $S$. agalactiae population significantly on silicone rubber tubing. Application of BS derived from L. paracasei subsp. paracasei A20 was found to be a potent antiadhesive molecule for elimination of fungal and bacterial pathogens on polystyrene surface (Gudina et al. 2011). BS was also found effective in prevention of colonization of yeast on medical surfaces. Anti-adhesive property of BS derived from Lactobacillus sp. against Candida albicans in pre-coating assay was able to reduced $82 \%$ at concentration of $312.5 \mu \mathrm{g} / \mathrm{ml}$ (Fracchia et al. 2010).
BS produced by E. faecium MRTL 9 strain was found to reduced microbial population from silicone tubing near to completely. BS showed anti-adhesive properties against commonly known biofilm formers on silicone tubing of medical equipment's and surgical implants. More than $95 \%$ reduction was achieved with $25 \mathrm{mg} \mathrm{ml}^{-1}$ of BS added to the growth medium. BS incorporated surface cleaning agents could be a next generation material for operational theater and highly sophisticated lab surfaces. The present study established a platform onwards in developing alternative strategies to prevent microbial colonization on surgical implants and silicone rubber prostheses.
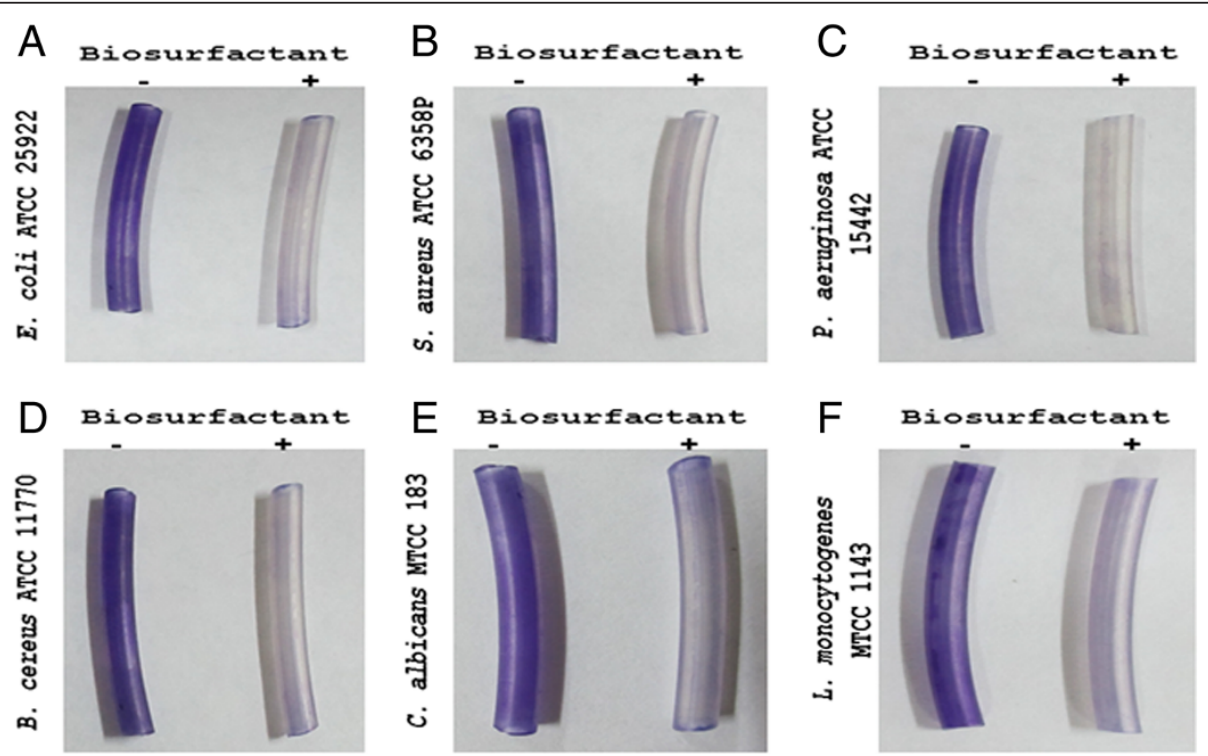

Figure 9 BS produced by E. faecium inhibits biofilm formation of (A) E. coli ATCC 25922 (B) S. aureus ATCC 6358P (C) P. aeruginosa ATCC 15442 (D) B. cereus ATCC 11770 (E) C. albicans MTCC183 (F) L. monocytogenes MTCC1143 on silicone tubes, (-) without BS treatment (+) with BS coating at the concentration of $25 \mathrm{mg} \mathrm{ml}^{-1}$. Biofilm inhibition was visualized by staining with crystal violet. 
Table 3 Removal of biofilm on polystyrene surfaces by biosurfactant isolated from $E$. faecium at different range of concentration ( $\mathrm{mg} \mathrm{ml}^{-1}$ )

\begin{tabular}{|c|c|c|c|c|c|c|}
\hline \multirow[t]{2}{*}{ Test organisms } & \multicolumn{5}{|c|}{ Biosurfactant (mg ml$\left.l^{-1}\right)$} & \multirow{2}{*}{$\begin{array}{c}\text { Contro } \\
\text { PBS } \\
\end{array}$} \\
\hline & 25 & 12.5 & 6.25 & 3.12 & 1.56 & \\
\hline E. coli & $95.4 \pm 0.65$ & $82.1 \pm 0.39$ & $74.1 \pm 0.15$ & $51 \pm 0.11$ & $40.9 \pm 0.36$ & 0 \\
\hline P. aeruginosa & $89.6 \pm 0.52$ & $69.2 \pm 0.25$ & $55.1 \pm 0.11$ & $44.1 \pm 0.16$ & $39.2 \pm 0.46$ & 0 \\
\hline S. aureus & $83.1 \pm 0.47$ & $73.3 \pm 0.38$ & $69.3 \pm 0.05$ & $55.3 \pm 0.30$ & $39 . \pm 0.14$ & 0 \\
\hline L. monocytogenes & $97.1 \pm 0.38$ & $84.3 \pm 0.38$ & $63.1 \pm 0.17$ & $49.3 \pm 0.32$ & $32.4 \pm 0.51$ & 0 \\
\hline B. cereus & $91.2 \pm 0.16$ & $79.3 \pm 0.28$ & $61.1 \pm 0.28$ & $39.2 \pm 0.20$ & $28.1 \pm 0.20$ & 0 \\
\hline Candida albicans & $65.3 \pm 0.16$ & $63.0 \pm 0.51$ & $44.1 \pm 0.17$ & $30.2 \pm 0.20$ & $19.4 \pm 0.45$ & 0 \\
\hline
\end{tabular}

\section{Biofilm removal on polystyrene surface}

The antibiofilm property of BS was evaluated against various pathogenic strains (Table 3). The BS showed antibiofilm activity against most of the pathogens but the spectrum of activity was varied for different microorganisms and also depends upon the concentration of the BS used. The highest antibiofilm property was observed against L. monocytogenes (97.1\%), E. coli $(95.4 \%)$ B. cereus (91.2\%), P. aeruginosa (89.6\%) S. aureus (83.1\%) and least antiadhesive potential was observed against C. albicans (65.3\%) strain. The antibiofilm activity against C. albicans was quite low even at the highest biosurfactant concentration assayed i.e. $25 \mathrm{mg} \mathrm{ml}^{-1}$. Biosurfactant produced by $E$. faecium MRTL 9 strain reduced biofilm on polystyrene surface near to completely. Contribution of biosurfactant in microbial desorption has been widely observed, and application of biosurfactant of lactobacilli to solid surfaces might be an effective approach to reduce microbial population of pathogenic strains (Rodrigues et al. 2006). The results of present experimental setup suggests the possible use of the BS of E. faecium as an alternative to conventional antimicrobial agents for bio-medical applications.

\section{Cytotoxicity assessment}

Nowadays there is an immense concern regarding the toxicity and safety of BS used for therapeutic purposes. So, there is an instant need to spot safety of BS. Cytotoxicity of BS was evaluated using mouse fibroblast (ATCC L929) cell line. The Mouse fibroblasts cells were selected and generally regarded suitable for cytotoxicity assessment. Mouse fibroblast cells are recommended for in vitro evaluation of medical devices by the International Organization for Standardization (2009). During cytotoxicity determination different concentrations of cell bound BS and purified rhamnolipids (Janeil, USA) were prepared in DMSO (Figure 10). Whereas SDS at equal concentration was used as negative control. Significant differences in cell viability of mouse fibroblasts cell was observed at concentration of $25 \mathrm{mg} \mathrm{ml}^{-1}, 12.5 \mathrm{mg} \mathrm{ml}^{-1}$

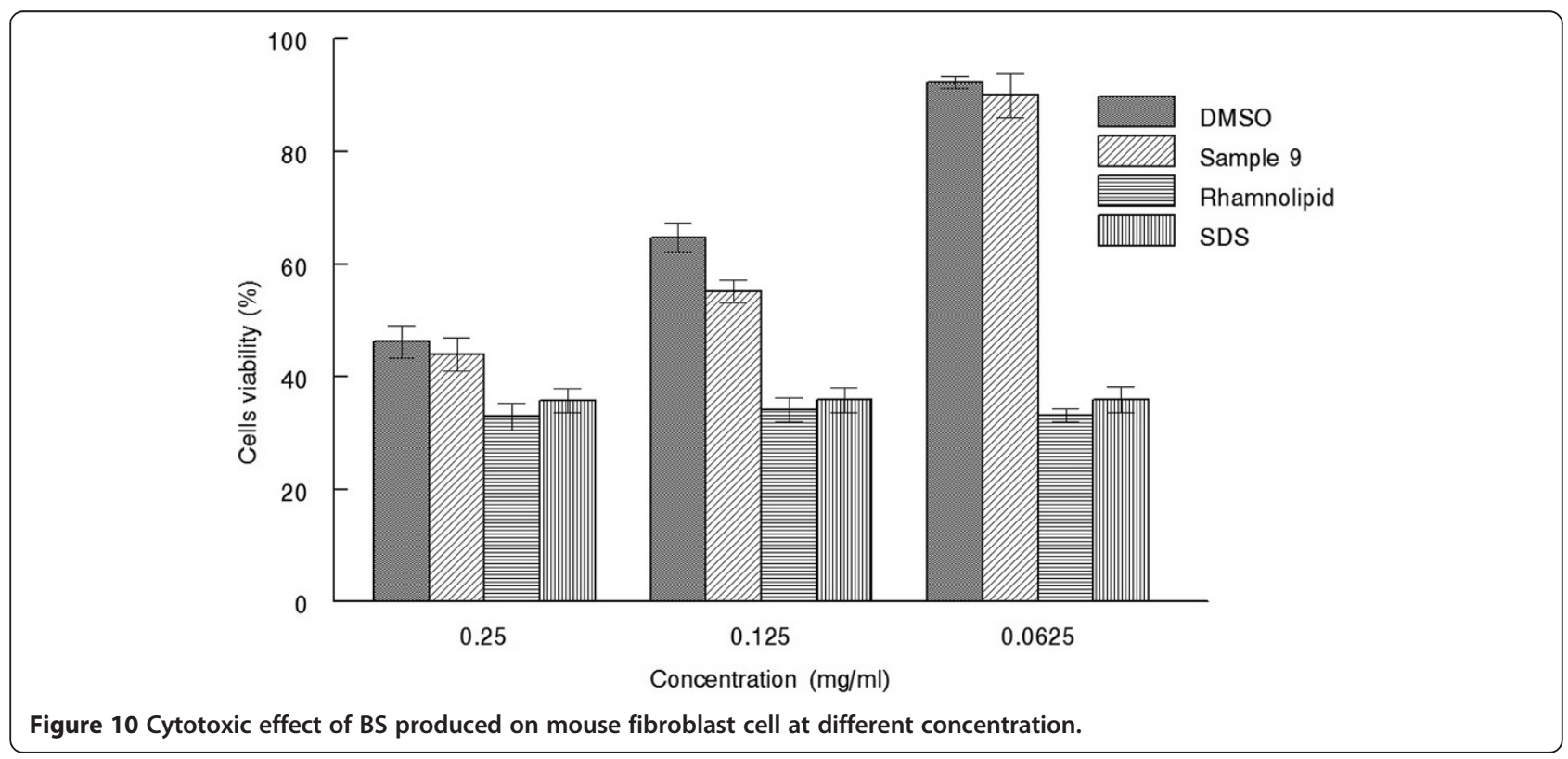


and $6.25 \mathrm{mg} \mathrm{ml}^{-1}$. Cell viability was found maximum about $90 \%$ at $6.25 \mathrm{mg} \mathrm{ml}^{-1}$ in case of BS produced by strain MRTL9 while positive control rhamnolipid showed $35.33 \%$ viability quiet close to SDS i.e. $35 \%$. But increase in the concentration of BS also declined the cellular viability. At concentration of $25 \mathrm{mg} \mathrm{ml}^{-1}$, cell viability was found 43.93\% as compared to rhamnolipid which showed $32.87 \%$ of cell viability. While DMSO used as diluent did not showed any significant cytotoxicity. A total of $92.27 \%$ cell viability was observed at $6.25 \mathrm{mg} \mathrm{ml}^{-1}$. The outcomes of cellular toxicity showed lower toxicity of BS in comparison to SDS and rhamnolipid. SDS has been admired as a reference irritant because of its fast-acting, non-allergenic, and toxicity (Effendy and Howard 1996).

Various reports on evaluation of cytotoxic evaluation of biosurfactant came in literature, the lack of cytotoxicity is anticipated when you wish to ecofriendly and safe antiadhesive suspension directly to be used for human applications and food applications. Typically, the cytotoxicity seems linked to its interactions with the phospholipids of cell membrane and therefore cell lysis. Cochis et al. (2012) has reported biosurfactants cytotoxicity on mouse fibroblast cell line with concentrations ranges from 25 to $6.25 \mu \mathrm{g} \mathrm{ml} \mathrm{m}^{-1}$. Pre-coating with BS caused a greater reduction in biofilm cell number and cell viability than chlorhexidine. BS produced by Sphingobacterium detergens was studied for its cytotoxicity and antiproliferative effects in different cell lines. When comparing cytotoxicity values $\left(\mathrm{IC}_{50}\right)$ of the two fractions in fibroblast and keratinocyte cell cultures, Fraction B was found less cytotoxic, showing lower toxicity than the reference compound SDS, indicating low skin irritability (Burgos-Díaz et al. 2013; Kumar et al. 2014). According to the outcomes of present study, BS produced by $E$. faecium interferes with microbial adhesion and demonstrate cyco-compatibility with mouse fibroblasts.

\section{Conclusion}

The BS produced by E. faecium MRTL 9 was isolated and structurally characterized as similar to Xylolipid. Structurally the BS characterized as a glycolipid with hexadecanoic fatty acid (C16) chain. In addition, biosurfactant was confirmed as non-cytotoxic compound as compared with other microbial and chemically synthesized surfactant. BS obtained from the LAB strain was found to be stable at different $\mathrm{pH}$ and also at elevated temperature ranges. Furthermore, due to its significant antiadhesive property and non-cytotoxic nature, the BS can potentially be used as a cleaning/coating material for bio-medical equipment's. The results obtained in this study regarding the antiadhesive properties of this lactobacilli derived BS also opens new future prospects for its use for combating microbial colonization, making it a suitable alternative to conventional antimicrobials.
Competing interests

The authors declare that they have no competing interests.

\section{Authors' contribution}

DS and BS carried out the microbiological, production and biotechnological part of the paper and drafted the manuscript, NC carried out the cytotoxicity part of study, SP and SL carried out the chemical characterization of biosurfactant. All authors read and approved the final manuscript.

\section{Acknowledgements}

Current research was supported by University grant commission (India) under the major research project. The infrastructural and financial support from Kurukshetra University. DAAD short term doctorate fellowship (Germany) is highly acknowledged.

\section{Author details}

'Department of Microbiology, Kurukshetra University, Kurukshetra 136 119, INDIA. ${ }^{2}$ Dairy Microbiology Division, National Dairy Research Institute, Karnal, Haryana 132 001, India. ${ }^{3}$ Division of Microbiology and Immunology, Vector Control Research Center, Puducherry 605006, India. ${ }^{4}$ Department of

Chemistry, Kurukshetra University, Kurukshetra 136 119, India.

Received: 7 July 2014 Accepted: 16 December 2014

Published: 7 January 2015

\section{References}

Abbasi H, Hamedi MM, Lotfabad TB, Zahiri HS, Sharafi H, Masoomi F, Noghabi KA (2012) Biosurfactant-producing bacterium Pseudomonas aeruginosa MA01 isolated from spoiled apples: Physicochemical and structural characteristics of isolated biosurfactant. J Biosci Bioeng 113(2):211-219

Albesharat R, Ehrmann MA, Korakli M, Yazaji S, Vogel RF (2011) Phenotypic and genotypic analyses of lactic acid bacteria in local fermented food, breast milk and faeces of mothers and their babies. Systematic Appl Microbiol 34(2):148-155

Augustine N, Kumar P, Thomas S (2010) Inhibition of Vibrio cholerae biofilm by AiiA enzyme produced from Bacillus sp. Arch Microbiol 192:1019-1022

Banat IM, Makkar RS, Cameotra SS (2000) Potential commercial applications of microbial surfactants. Appl Microbial Biotechnol 53(5):495-508

Banat IM, Franzetti A, Gandolfi I, Bestetti G, Martinotti MG, Fracchia L, Marchant R (2010) Microbial biosurfactants production, applications and future potential. Appl Microbiol Biotechnol 87(2):427-444

Burgos-Díaz C, Pons R, Teruel JA, Aranda FJ, Ortiz A, Manresa A, Marqués AM (2013) The production and physicochemical properties of a biosurfactant mixture obtained from Sphingobacterium detergens. J Colloid Interface Sci 394:368-379

Busscher HJ, Van der Mei HC (1997) Physico-chemical interactions in initial microbial adhesion and relevance for biofilm formation. Adv dental res 11(1):24-32

Busscher HJ, Neu TR, Van der Mei HC (1994) Biosurfactant production by thermophilic dairy streptococci. Appl microbiol biotechnol 41(1):4-7

Busscher HJ, van Hoogmoed CG, Geertsema-Doornbusch Gl, van der Kuijl-Booij M, van der Mei HC (1997) Streptococcus thermophilus and its biosurfactants inhibit adhesion by Candida spp. on silicone rubber. Appl Environ Microbiol 63:3810-3817

Carrillo PG, Mardaraz C, Pitta-Alvarez SI, Giulietti AM (1996) Isolation and selection of biosurfactant-producing bacteria. World J Microbiol Biotechnol 12(1):82-84

Cochis A, Fracchia L, Martinotti MG, Rimondini L (2012) Biosurfactants prevent in vitro Candida albicans biofilm formation on resins and silicon materials for prosthetic devices. Oral Surg Oral Med Oral Pathol Oral Radiol 113(6):755-761

Desai JD, Banat IM (1997) Microbial production of surfactants and their commercial potential. Microbiol Mol Biol Rev 61(1):47-64

Effendy I, Howard IM (1996) Detergent and skin irritation. Clin Dermatol 14(1):15-21

Falagas ME, Makris GC (2009) Probiotic bacteria and biosurfactants for nosocomial infection control: a hypothesis. J Hospital Inf 71(4):301-306

Faria AF, Teodoro-Martinez DS, de Oliveira Barbosa GN, Gontijo Vaz B, Serrano Silva I, Garcia JS, Regina Durrant L (2011) Production and structural characterization of surfactin produced by Bacillus subtilis isolate LSFM-05 grown on raw glycerol from the biodiesel industry. Process Biochem 46(10):1951-1957 
Fracchia L, Cavallo M, Allegrone G, Martinotti MG (2010) A Lactobacillus-derived biosurfactant inhibits biofilm formation of human pathogenic Candida albicans biofilm producers. Appl Microbiol Biotechnol 2:827-837

Golek P, Bednarski W, Brzozowski B, Dziuba B (2009) The obtaining and properties of biosurfactants synthesized by bacteria of the genus Lactobacillus. Ann Microbiol 59(1):119-126

Grosu-Tudor SS, Zamfir M, Van der Meulen R, De Vuyst L (2013) Isolation of novel homopolysaccharide-producing lactic acid bacteria from Romanian raw milk and fermented dairy products. Eur Food Res Technol 237(4):609-615

Gudina EJ, Teixeira JA, Rodrigues LR (2011) Effect of biosurfactant and fertilizer on biodegradation of crude oil by marine isolates of Bacillus megaterium, Corynebacterium kutscheri and Pseudomonas aeruginosa. Appl Environ Soil Sci 2011:1-6

Gutierrez T, Leo W, Walker GM, Green DH (2009) Emulsifying properties of a glycoprotein extract produced by a marine Flexibacterspecies strain TG382 Enz Microbiol. Technol 45:53-57

Heinemann C, Van Hylckama V, Janssen D, Busscher H, Van der Mei HC, Reid G (2000) Purification and characterization of a surface-binding protein from Lactobacillus fermentum RC-14 that inhibits adhesion of Enterococcus faecalis 1131. FEMS Microbiol Lett 40:175-179

Henkel M, Müller MM, Kügler JH, Lovaglio RB, Contiero J, Syldatk C, Hausmann R (2012) Rhamnolipids as biosurfactants from renewable resources: concepts for next-generation rhamnolipid production. Process Biochem 47(8):1207-1219

Hormann B, Muller MM, Syldatk C, Hausmann R (2010) Rhamnolipid production by Burkholderia plantarii DSM9509T. Eur J Lipid Sci Technol 112:674-680

International Organization for Standardization (2009) Biological evaluation of medical devices-part 5 Tests for in vitro cytotoxicity. Int. Organization Standardization, Geneve

Jain RM, Mody K, Joshi N, Mishra A, Jha B (2013) Production and structural characterization of biosurfactant produced by an alkaliphilic bacterium Klebsiella sp:: Evaluation of different carbon sources. Colloids and Surf B: Biointerfaces 108:199-204

Janek T, Łukaszewicz M, Krasowska A (2013) Identification and characterization of biosurfactants produced by the Arctic bacterium Pseudomonas putida BD2. Colloids Surf B: Biointerfaces 110:379-386

Juwarkar AA, Nair A, Dubey KV, Singh SK, Devotta S (2007) Biosurfactant technology for remediation of cadmium and lead contaminated soils. Chemosphere 10:1996-2002

Khire JM (2010) Bacterial biosurfactants and their role in microbial enhanced oil recovery (MEOR). Biosurfactants, Landes Bioscience, In, pp 146-157

Kumar V, Kumari A, Kumar D, Yadav SK (2014) Biosurfactant stabilized anticancer biomolecule-loaded poly (d, I-lactide) nanoparticles. Colloids Surf B: Biointerf 117:505-511

Lang S (2002) Biological amphiphiles (microbial biosurfactants). Curr Opinion Colloid and Interface Sci 7(1):12-20

Lotfabad TB, Abassi H, Ahmadkhaniha R, Roostaazad F, Masoomi HS, Zahiri G, Ahmadian H, Vali, Noghabi KA (2013) Structural characterization of a rhamnolipid-type biosurfactant produced by Pseudomonas aeruginosa MR01: enhancement of di-rhamnolipid proportion using gamma irradiation. Colloids Surf B: Biointerf 81:397-405

Madhu AN, Prapulla SG (2014) Evaluation and functional characterization of a biosurfactant produced by Lactobacillus plantarum CFR 2194. Appl Biochem Biotechnol 172(4):1777-1789

Meylheuc T, Van Oss CJ, Bellon-Fontaine MN (2001) Adsorption of biosurfactant on solid surfaces and consequences regarding the bio-adhesion of Listeria monocytogenes LO28. J Appl Microbiol 91(5):822-832

Mohebali G, Ball A, Kaytash A, Rasekh B (2007) Stabilization of water/gas oil emulsions by desulfurizing cells of Gordonia alkanivorans RIPI90A. Microbiol 153(5):1573-1581

Moldes AB, Paradelo R, Vecino X, Cruz JM, Gudina E, Rodrigues L, Barral MT (2013) Partial Characterization of Biosurfactant from Lactobacillus pentosus and comparison with Sodium Dodecyl Sulphate for the bioremediation of hydrocarbon contaminated soil. BioMed Res Int 2013:1-6

Monteiro AS, Miranda TT, Lula I, Denadai ÂM, Sinisterra RD, Santoro MM, Santos VL (2011) Inhibition of Candida albicans CC biofilms formation in polystyrene plate surfaces by biosurfactant produced by Trichosporon montevideense CLOA72. Colloids Surf B: Biointerf 84(2):467-476

Morikawa M, Daido H, Takao T, Murata S, Shimonishi Y (1993) Ima-naka TJ (1993) A new lipopeptide biosurfactant produced by Arthrobacter sp. strain MIS38. Bacteriol 175:6459-6466
Morita T, Fukuoka T, Imura T, Kitamoto D (2012) Formation of the two novel glycolipid biosurfactants, mannosylribitol lipid and mannosylarabitol lipid, by Pseudozyma parantarctica JCM 11752 T. Appl microbiol biotechnol 96(4):931-938

Mulligan CN (2005) Environmental applications for biosurfactants. Environ Pollution 133(2):183-198

Myers D (2005) Surfactant Science and Technology. In: Surfactant Science and Technology, 3rd edn. Wiley-Interscience, USA

Neu TR, Härtner T, Poralla K (1990) Surface active properties of viscosin: a peptidolipid antibiotic. Appl microbiol biotechnol 32(5):518-520

Nitschke M, Araujo LV, Costa S, Pires RC, Zeraik AE, Fernandes A, Freire D, Contiero J (2009) Surfactin reduces the adhesion of food-borne pathogenic bacteria to solid surfaces. Lett Appl Microbiol 49:241-247

Nitschke M, Siddhartha G, Costa J, Jonas C (2011) Rhamnolipids and PHAs: Recent reports on Pseudomonas derived molecules of increasing industrial interest. Process Biochem 46:621-630

Oliveira JGD, Garcia-Cruz CH (2013) Properties of a biosurfactant produced by Bacillus pumilus using vinasse and waste frying oil as alternative carbon sources. Braz Arch Biol Technol 56(1):155-160

Pornsunthorntawee O, Wongpanit P, Chavadej S, Abe M, Rujiravanit R (2008) Structural and physicochemical characterization of crude biosurfactant produced by Pseudomonas aeruginosa SP4 isolated from petroleum-contaminated soil. Bioresource Technol 99(6):1589-1595

Rodrigues LR, Van der Mei HC, Teixeira JA, Oliveira R (2004) Influence of biosurfactants from probiotic bacteria on formation of biofilms on voice prosthesis. Appl Environ Microbiol 70:4408-4410

Rodrigues L, Banat IM, Teixeira J, Oliveira R (2006a) Biosurfactants: potential applications in medicine. J Antimicrobial Chemotherapy 57(4)(4):609-618

Rodrigues LR, Teixeira JA, Van der Mei HC, Oliveira R (2006b) Isolation and partial characterization of a biosurfactant produced by Streptococcus thermophiles. Colloids Surfaces B: Biointerfaces 53:105-112

Rodriguez-Pazo N, Salgado JM, Cortes-Dieguez S, Dominguez JM (2013) Biotechnological production of phenyllactic acid and biosurfactants from trimming vine shoot hydrolyzates by microbial Co-culture fermentation. Appl Biochem Biotechnol 2:1-14

Rufino RD, Sarubbo LA, Neto BB, Campos-Takaki GM (2008) Experimental design for the production of tensio-active agent by Candida lipolytica. J Ind Microbiol Biotechnol 35(8):907-914

Saharan BS, Sahu RK, Sharma D (2011) A review on biosurfactants: fermentation, current developments and perspectives Gen Eng. Biotechnol J 2011:1-14

Saharan BS, Grewal A, Kumar P (2014) Biotechnological production of polyhydroxyalkanoates: a review on trends and latest developments. Chinese J Biol 2014:1-18

Saravanakumari P, Mani K (2010) Structural characterization of a novel xylolipid biosurfactant from Lactococcus lactis and analysis of antibacterial activity against multi-drug resistant pathogens. Bioresource Technol 101(22):8851-8854

Sauvageau J, Ryan J, Lagutin K, Sims IM, Stocker BL, Timmer MS (2012) Isolation and structural characterization of the major glycolipids from Lactobacillus plantarum. Carbohydrate Res 357:151-156

Schenk T, Schuphan I, Schmidt B (1995) High-performance liquid chromatographic determination of the rhamnolipids produced by Pseudomonas aeruginosa. J Chromatograph A 693:7-13

Schippers C, Gessner K, Müller T, Scheper T (2000) Microbial degradation of phenanthrene by addition of a sophorolipid mixture. J Biotechnol 83(3):189-198

Servin AL (2004) Antagonistic activities of lactobacilli and bifidobacteria against microbial pathogens. FEMS Microbiol Rev 28:405-440

Sharma D, Singh BS (2014) Simultaneous Production of biosurfactants and bacteriocins by probiotic Lactobacillus casei MRTL3. Int J Microbio 2014:1-7

Sheu DS, Wang YT, Lee CY (2000) Rapid detection of polyhydroxyalkanoate accumulating bacteria isolated from the environment by colony PCR. Microbiol 146:2019-2025

Syldatk C, Lang S, Matulovic U, Wagner F (1985) Production of four interfacial active rhamnolipids from $n$-alkanes or glycerol by resting cells of Pseudomonas species DSM 2874. Zeitschrift fur Naturforschung Section C: Biosci 40:61-67

Tahmourespour A, Salehi R, Kermanshahi RK, Eslami G (2011) The anti-biofouling effect of Lactobacillus fermentum-derived biosurfactant against Streptococcus mutans. Biofouling 27(4):385-392

Thavasi R, Jayalakshmi S, Balasubramanian T, Banat IM (2008) Production and characterization of a glycolipid biosurfactant from Bacillus megaterium using economically cheaper sources. World J Microbiol Biotechnol 24(7):917-925 
Thavasi R, Jayalakshmi S, Banat IM (2011) Effect of biosurfactant and fertilizer on biodegradation of crude oil by marine isolates of Bacillus megaterium Corynebacterium kutscheri and Pseudomonas aeruginosa. Bioresource Technology 102(2):772-778

Van der Mei HC, Free RH, Elving GJ, van Weissenbruch R, Albers F, Busscher HJ (2000) Effect of probiotic bacteria on Probiotic organisms for infection control and prevalence of yeasts in oropharyngeal biofilms on silicone rubber voice prostheses in vitro. J Med Microbiol 49:713-718

Van Hoogmoed CG, van Der Kuijl-Booij M, van der Mei HC, Busscher HJ (2000) Inhibition of Streptococcus mutans NS adhesion to glass with and without a salivary conditioning films by biosurfactant-releasing Streptococcus mitis strains. Appl Environ Microbiol 66:659-663

Vaz DA, Gudiña EJ, Alameda EJ, Teixeira JA, Rodrigues LR (2012) Performance of a biosurfactant produced by a Bacillus subtilis strain isolated from crude oil samples as compared to commercial chemical surfactants. Colloids Surf B: Biointerf 89:167-174

Vecino X, Barbosa-Pereira L, Devesa-Rey R, Cruz JM, Moldes AB (2014) Optimization of extraction conditions and fatty acid characterization of $L$. Pentosus cell bound Biosurfactant/Bioemulsifier. J Sci Food Agric 2014:1313-1320

Velraeds MM, Van der Mei HC, Reid G, Busscher HJ (1996) Inhibition of initial adhesion of uropathogenic Enterococcus faecalis by biosurfactants from Lactobacillus isolates. Appl Environ Microbiol 62:1958-1963

Velraeds MMC, Van der Mei HC, Reid G, Busscher HJ (1997) Inhibition of initial adhesion of uropathogenic Enterococcus faecalis to solid substrata by an adsorbed biosurfactant layer from Lactobacillus acidophilus. Urol 49:790-794

Velraeds MM, van de Belt-Gritter B, Busscher HJ, Reid G, van der Mei HC (2000) Inhibition of uropathogenic biofilm growth on silicone rubber in human urine by lactobacilli-a teleologic approach. World J Urol 18:422-426

Walencka E, Rozalska S, Sadowska B, Rożalska B (2008) The influence of Lactobacillus acidophilus derived surfactants on staphylococcal adhesion and biofilm formation. Folia Microbiologia 53:61-66

Youssef NH, Duncan KE, Nagle DP, Savage KN, Knapp RM, Mclnerney MJJ (2004) Comparison of methods to detect biosurfactant production by diverse microorganisms. Microbiol Methods 56(3):339-347

doi:10.1186/2193-1801-4-4

Cite this article as: Sharma et al:: Isolation and functional characterization of novel biosurfactant produced by Enterococcus faecium. SpringerPlus 2015 4:4.

\section{Submit your manuscript to a SpringerOpen ${ }^{\circ}$ journal and benefit from:}

- Convenient online submission

- Rigorous peer review

- Immediate publication on acceptance

- Open access: articles freely available online

- High visibility within the field

- Retaining the copyright to your article

Submit your next manuscript at $\gg$ springeropen.com 